Biochimica et Biophysica Acta, 610 (1980) 181-188

(C) Elsevier/North-Holland Biomedical Press

BBA 99766

\title{
PURIFICATION AND CHARACTERIZATION OF PROTEIN SYNTHESIS INITIATION FACTOR EIF-3 FROM WHEAT GERM
}

\author{
EWA CEGLARZ *, HANS GOUMANS, ADRI THOMAS and ROB BENNE ** \\ Department of Molecular Cell Biology, State University of Utrecht, Transitorium 3, \\ Padualaan 8, $3584 \mathrm{CH}$ Utrecht (The Netherlands)
}

(Received June 24th, 1980).

Key words: Initiation factor elF-3; Protein synthesis; (Wheat germ)

\section{Summary}

eIF-3 from wheat germ is a large multicomponent factor. It sediments at $15 \mathrm{~S}$ and is comprised of ten different polypeptides with an $M_{\mathrm{r}}$ value ranging from 26000 to 135000 ; five out of the ten seem to be present in a $1: 1$ stoichiometric ratio, whereas the others appear to occur approximately in a 0.5 to 1 ratio.

The factor is active in a partially purified cell-free system derived from wheat germ and in a mammalian model assay system for the synthesis of methionyl puromycin.

\section{Introduction}

By far the most complex protein factor involved in eukaryotic protein synthesis is initiation factor eIF-3. It is a multi-component assemblage, consisting of at least eight polypeptides, with a total mass of approximately $700000 \mathrm{dal}-$ tons [1-5]. The factor plays an important role in the initiation process, since it interacts with the small ribosomal subunit at a very early stage, thereby preventing premature formation of $80-S$ ribosomes [6-8]. The resulting eIF-340-S complex is the starting material in a sequence of events which eventually lead to the construction of an $80 \mathrm{~S}$ initiation complex. The presence of the factor on $40 \mathrm{~S}$ has been found to be required for optimal Met-tRNA and mRNA binding [6-9] (see for a review, Ref. 10).

\footnotetext{
* Present address: Institute of Biochemistry, Agricultural University, Ulica Wotynska, PL-60-637 Poznán, Poland.

** To whom correspondence should be addressed.

Abbreviation: eIF, eukaryotic initiation factor.
} 
The complex nature of the factor may be a reflexion of its multiple functions [8], or be connected with specificity of messenger selection [11]. Most of the information on the factor has been derived from rabbit reticulocytes [ $1-3$, 6-9] and, less detailed, from rat liver [4] and wheat germ [5].

In order to obtain a better-defined cell-free system for protein synthesis from wheat germ, we have undertaken the task of purifying and characterizing the most essential initiation factors. A previous paper [12] described the purification of the Met-tRNA $A_{f}$ binding factor eIF-2. Here we present a thorough characterization of eIF-3, with emphasis on the number, molecular weight and stoichiometry, of its subunits, information which has not been available so far (see Ref. 5).

\section{Materials and Methods}

\section{Materials}

$\left[{ }^{35} \mathrm{~S}\right]$ Methionine $(600 \mathrm{Ci} / \mathrm{mmol})$ and $\left[{ }^{3} \mathrm{H}\right]$ methionine $(8.8 \mathrm{Ci} / \mathrm{mmol})$ were purchased from the Radiochemical Centre, Amersham, U.K., Sephadex G-25 and Sepharose 6B from Pharmacia, DEAE-cellulose (DE-52) from Whatman, and commercial wheat germ from General Mills (Vallejo, U.S.A.).

\section{Buffers}

The compositions of these were: buffer A, $20 \mathrm{mM}$ Tris-HCl, $\mathrm{pH} 7.6 / 2 \mathrm{mM}$ magnesium acetate $/ 7 \mathrm{mM}$ 2-mercaptoethanol/120 mM KCl; buffer $\mathrm{B}, 20 \mathrm{mM}$ Tris-HCl, pH 7.6/4 mM magnesium acetate $/ 7 \mathrm{mM}$ 2-mercaptoethanol $/ 100 \mathrm{mM}$ $\mathrm{KCl} / 0.25 \mathrm{M}$ sucrose; buffer C, $20 \mathrm{mM}$ Tris-HCl, $\mathrm{pH}$ 7.6/7 mM 2-mercaptoethanol/10\% glycerol; buffer $\mathrm{D}, 20 \mathrm{mM}$ Tris-HCl, $\mathrm{pH}$ 7.6/7 mM 2-mercaptoethanol/100 $\mathrm{mM} \mathrm{KCl}$.

\section{Biological components}

The preparation of the following components has been described: Sepharoseheparin [13], hemoglobin $9 \mathrm{~S}$ mRNA [14], crude and purified initiation factors from rabbit reticulocytes [15-18], pH 5 enzymes from rat liver [19], ribosomal subunits from rat liver [20], [ $\left.{ }^{3} \mathrm{H}\right]$ Met-tRNA $4000 \mathrm{cpm} / \mathrm{pmol}$ [12], $23000 \times g$ homogenate from wheat germ [21].

Wheat-germ S23 homogenate prepared from $62.5 \mathrm{~g}$ of dry wheat germ was passed through a 1.81 Sephadex G-25 column equilibrated in buffer A according to Spremulli et al. [5]. Fractions eluting at the void volume of the column were combined (total volume of four preparations: $1770 \mathrm{ml}$ ), clarified, and centrifuged in 84-ml portions through $10 \mathrm{ml} 1 \mathrm{M}$ sucrose in buffer A in a Beckmann $\mathrm{Ti} 45$ rotor for $16 \mathrm{~h}$ at $35000 \mathrm{rev} . / \mathrm{min}$. The resulting ribosomal pellet was resuspended in buffer $B$ and used as a source of wheat germ ribosomes devoid of initiation factors. The S100 supernatant was used as the starting material for the preparation of initiation factors (see Table I). pH 4.5 enzymes from wheat germ were prepared from the protein fraction that did not adsorb to Sepharose-heparin (see Ref. 19).

\section{Assays}

Formation of methionyl puromycin: this assay system has been described 
elsewhere [12]. Protein synthesis in a mammalian pH 5 system: for this assay see Ref. 22. Protein synthesis in a wheat germ $\mathrm{pH} 4.5$ system: a typical assay mixture of $25 \mu$ l contained: $80 \mathrm{mM} \mathrm{KCl}, 0.6 \mathrm{mM}$ magnesium acetate, $20 \mathrm{mM}$ Hepes/KOH, pH 7.6, $1 \mathrm{mM}$ ATP $\cdot \mathrm{Mg}^{2+}, 0.4 \mathrm{mM}$ GTP $\cdot \mathrm{Mg}^{2+}, 5 \mathrm{mM}$ creatine phosphate, $1 \mathrm{mM}$ dithiothreitol, 0.2 unit of creatine kinase, $100 \mu \mathrm{M}$ spermine, $0.3 \mu \mathrm{M}\left[{ }^{35} \mathrm{~S}\right]$ methionine, $50 \mu \mathrm{M}$ each of 19 unlabeled amino acids, $1 \mu \mathrm{g}$ globin mRNA, $10 \mathrm{pmol}$ of wheat germ ribosomes, $30 \mu \mathrm{g}$ of crude initiation factors fraction BC (see Refs. 18, 22), $2 \mu \mathrm{g}$ of purified eIF-4B from rabbit reticulocytes, $19 \mu \mathrm{g}$ of $\mathrm{pH} 4.5$ fraction from wheat germ and eIF-3 as indicated.

The samples were incubated for $30 \mathrm{~min}$ at $25^{\circ} \mathrm{C}$. Incorporation of $\left[{ }^{35} \mathrm{~S}\right]$ methionine was measured by hot trichloroacetic acid precipitation. Protein concentrations were determined according to Layne [23].

\section{Results and Discussion}

\section{The purification of eIF-3 from wheat germ}

The S100 fraction from $4 \times 62.5 \mathrm{~g}$ of wheat germ was prepared as described under Materials and Methods. This material (16.7 $\mathrm{g}$ of protein in $2200 \mathrm{ml}$ ) was applied onto a $200 \mathrm{ml}$ column of Sepharose-heparin equilibrated in buffer C containing $100 \mathrm{mM} \mathrm{KCl}$. The proteins that did not adsorb were used as a source of pH 4.5 enzymes. Adsorbed proteins were eluted with buffer $\mathrm{C}$ containing $500 \mathrm{mM} \mathrm{KCl}$. The fractions were pooled $(445 \mathrm{ml}, 3.9 \mathrm{mg} / \mathrm{ml})$ and the proteins fractionated with ammonium sulphate between 0-40\% (fraction A) and 40$70 \%$ (fraction $\mathrm{BC}$ ) as described [16,17]. Fraction BC contained no eIF-3 and was further used in the assays as a source of all other initiation factors (except eIF-4B).

Fraction A $(6.9 \mathrm{ml}, 84.0 \mathrm{mg} / \mathrm{ml})$ was dialyzed against buffer $\mathrm{D}$ and applied onto gradients of $15-31 \%$ sucrose in buffer $D$ in portions of $30 \mathrm{mg}$ protein per gradient. Centrifugation was carried out in a Beckman SW 27 rotor for $41 \mathrm{~h}$ at $26000 \mathrm{rev} . / \mathrm{min}$. The gradients were collected in fractions of $2 \mathrm{ml}$, and $10 \mu \mathrm{l}$ of each fraction was tested for eIF-3 activity (see Materials and Methods and Figs. 2 and 3). Active fractions were combined and concentrated by ammonium sulphate precipitation ( $50 \%$ saturation) to $7.9 \mathrm{ml}, 7.0 \mathrm{mg} / \mathrm{ml}$, in buffer $\mathrm{C}$ containing $50 \mathrm{mM} \mathrm{KCl}$.

This fraction was applied onto a $30 \mathrm{ml}$ column of DEAE-cellulose equilibrated in the same buffer. Adsorbed proteins were eluted with a $120 \mathrm{ml}$ gradient of $50-300 \mathrm{mM} \mathrm{KCl}$ in buffer $\mathrm{C}$.

100- $\mu$ l aliquots of each $2 \mathrm{ml}$ fraction were dialyzed against buffer $\mathrm{C}$ containing $100 \mathrm{mM} \mathrm{KCl} .10-\mu l$ of these aliquots were assayed for eIF-3 activity (see Materials and Methods and Figs. 2 and 3). eIF-3 activity eluted between 180 and $250 \mathrm{mM} \mathrm{KCl}$. Active fractions were pooled and concentrated with ammonium sulphate and dialyzed against buffer $\mathrm{C}$ containing $100 \mathrm{mM} \mathrm{KCl}$.

Small $(250-\mu \mathrm{l})$ portions of this fraction $(1.3 \mathrm{ml}, 12.8 \mathrm{mg} / \mathrm{ml})$ were applied onto 15-31\% gradients of sucrose in buffer $D$ and centrifuged for $18 \mathrm{~h}$ at $32000 \mathrm{rev} . / \mathrm{min}$ in a Beckman SW 50 rotor. 10- $\mu$ l aliquots of each fraction $(250-\mu l)$ were assayed for eIF-3 activity (see Fig. 2).

The eIF-3 containing fractions were kept separate and used for the elucidation of the subunit composition of the factor (see next section, and Fig. 2). A 
TABLE I

SUMMARY OF PURIFICATION OF EIF-3

1 unit of activity is the amount of elF-3 which stimulates the formation of 1 pmol of $\left[{ }^{3} \mathrm{H}\right]$ methionyl puromycin under standard assay conditions as described [12]. Limiting amounts of factor (5-10 $\mu \mathrm{g}$, see Fig. 3) were tested for each purification step. eIF-3 activity in the S100 Sepharose-heparin fractions could not be determined because these fractions contained components inhibitory to the assay system.

\begin{tabular}{lcccc}
\hline Step & $\begin{array}{l}\text { Protein } \\
(\mathrm{mg})\end{array}$ & $\begin{array}{l}\text { Activity } \\
\text { (units) }\end{array}$ & $\begin{array}{l}\text { Recovery } \\
(\%)\end{array}$ & $\begin{array}{l}\text { Specific } \\
\text { activity } \\
\text { (units/mg) }\end{array}$ \\
\hline S100 & 16900 & - & - & - \\
Sepharose-heparin & 1735 & - & - & - \\
Ammonium sulphate (0-40\%) & 580 & 12470 & $\mathbf{1 0 0}$ & $\mathbf{2 1 . 5}$ \\
Sucrose gradient I & 55.1 & $\mathbf{2 9 1 4}$ & $\mathbf{2 3 . 4}$ & $\mathbf{8 2 . 9}$ \\
DEAE-cellulose & 16.1 & $\mathbf{1 3 1 8}$ & $\mathbf{8 1 . 9}$ & $\mathbf{7 5 4 . 3}$ \\
Sucrose gradient II & 6.0 & $\mathbf{9 2 6}$ & $\mathbf{7 . 4}$ & \\
\hline
\end{tabular}

summary of the purification procedure of eIF-3 is presented in Table I. $6 \mathrm{mg}$ of purified eIF-3 was obtained from $250 \mathrm{~g}$ of wheat germ.

The increase in specific activity of the eIF-3 fractions upon purification is not spectacular: a 7.5-fold enrichment was obtained (compare the ammonium sulphate fraction to the sucrose gradient II fraction).

Apparently, the bulk of contaminating proteins has been removed during the first steps of the purification procedure, suggesting that the ammonium sulphate A fraction is already relatively rich in eIF-3. This assumption is supported by gel analysis of the different eIF-3 fractions (see next section, Fig. 1). Furthermore, a similar observation has been made in rabbit reticulocytes (compare Ref. 1).

\section{Physical characterization of eIF-3 from wheat germ}

The analysis on sodium dodecyl sulphate slab gels of eIF-3 fractions from each purification step is shown in Fig. 1 , lanes $I-V$. The relative intensity of a number of bands increases during purification. These bands could be tentatively considered as subunits of eIF-3 and are numbered 1-9 (Fig. 1, lane V). A strong indication that these proteins indeed compose eIF-3 came from a comparison of the activity profiles and gel analysis of the fractions from the sucrose gradient I step (not shown), the DEAE-cellulose step (not shown) and the sucrose gradient II step (Fig. 2). eIF-3 activity in the two assay-systems tested (Fig. 2A) seems to coincide with those fractions containing the numbered polypeptides of Fig. 1, lane V (Fig. 2B).

These polypeptides appear to sediment at approximately $15 \mathrm{~S}$ as a large complex comparable to the factor from reticulocytes [1-3], although most of its subunits seem to be different (Fig. 1, lanes V and VI). The interaction between these polypeptides is sufficiently strong to survive a sucrose gradient centrifugation step at $0.5 \mathrm{M} \mathrm{KCl}$, since gel analysis of the fractions of such a gradient shows a pattern indistinguishable from the one of Fig. 2B.

Table II lists the tentative subunits of eIF-3 from wheat germ together with their molecular weights and apparent stoichiometry as derived from the absorbance tracings of the gels of Fig. 2B. The molecular weights range from 26000 


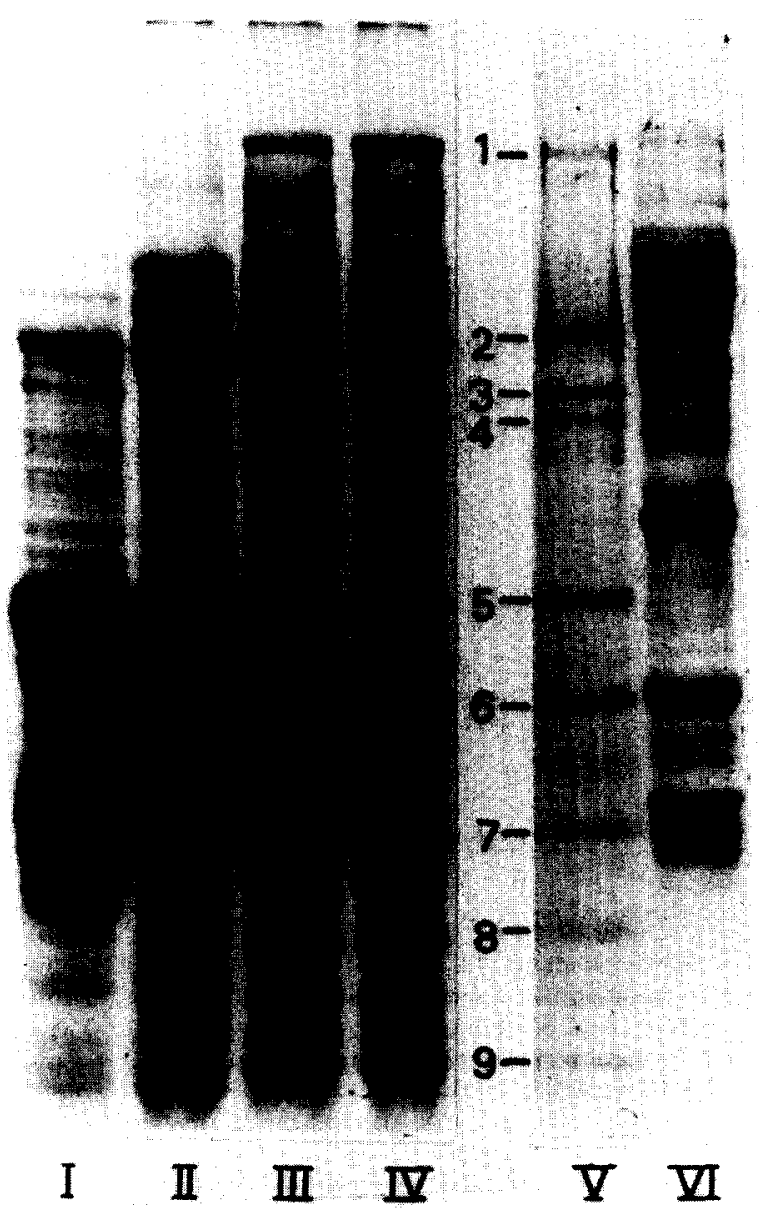

Fig. 1. Gel analysis of eIF-3 fractions. Sodium dodecyl sulphate polyacrylamide gel electrophoresis was performed on $10 \%$ slab gels according to Laemmli [24]. The slots contained in $50 \mu 1$ sample buffer (see Ref. 24): I, $180 \mu \mathrm{g}$ eIF-3 following Sepharose-heparin; II, $170 \mu \mathrm{g}$ elF-3 following ammonium sulphate fractionation; III, $210 \mu \mathrm{g}$ elF-3 following sucrose gradient I; IV, $130 \mu \mathrm{g}$ eIF-3 following DEAE-cellulose; $\mathrm{V}, 16 \mu \mathrm{g}$ elF-3 following sucrose gradient II; VI, $35 \mu \mathrm{g}$ eIF-3 from rabbit reticulocytes. The numbers in the figure next to lane $V$ correspond to the positions of the subunits of elF-3 from wheat germ (see Table II).

to 135000 . It is striking that five out of the ten subunits $(2,5,6,8$ and 9$)$ appear to be present in equimolar amounts, whereas $1,3,4,7 \mathrm{a}$ and $7 \mathrm{~b}$ occur approximately in a 0.5 to 1.0 ratio with respect to the others.

Similar heterogeneity was observed for the reticulocyte factor [1-3]. It has been postulated that the different forms of eIF-3 possess different biological properties (Refs. 8, 11; see Introduction). On the other hand, the possibility arises that subequimolar proteins originate from limited proteolysis of larger precursors.

It is not clear whether the other proteins present in at least a part of the active fractions of Fig. 2B play any role in eIF-3 functioning. Only those that closely follow the activity profile of Fig. 2A and other purification steps (not shown) are listed in Table II. 


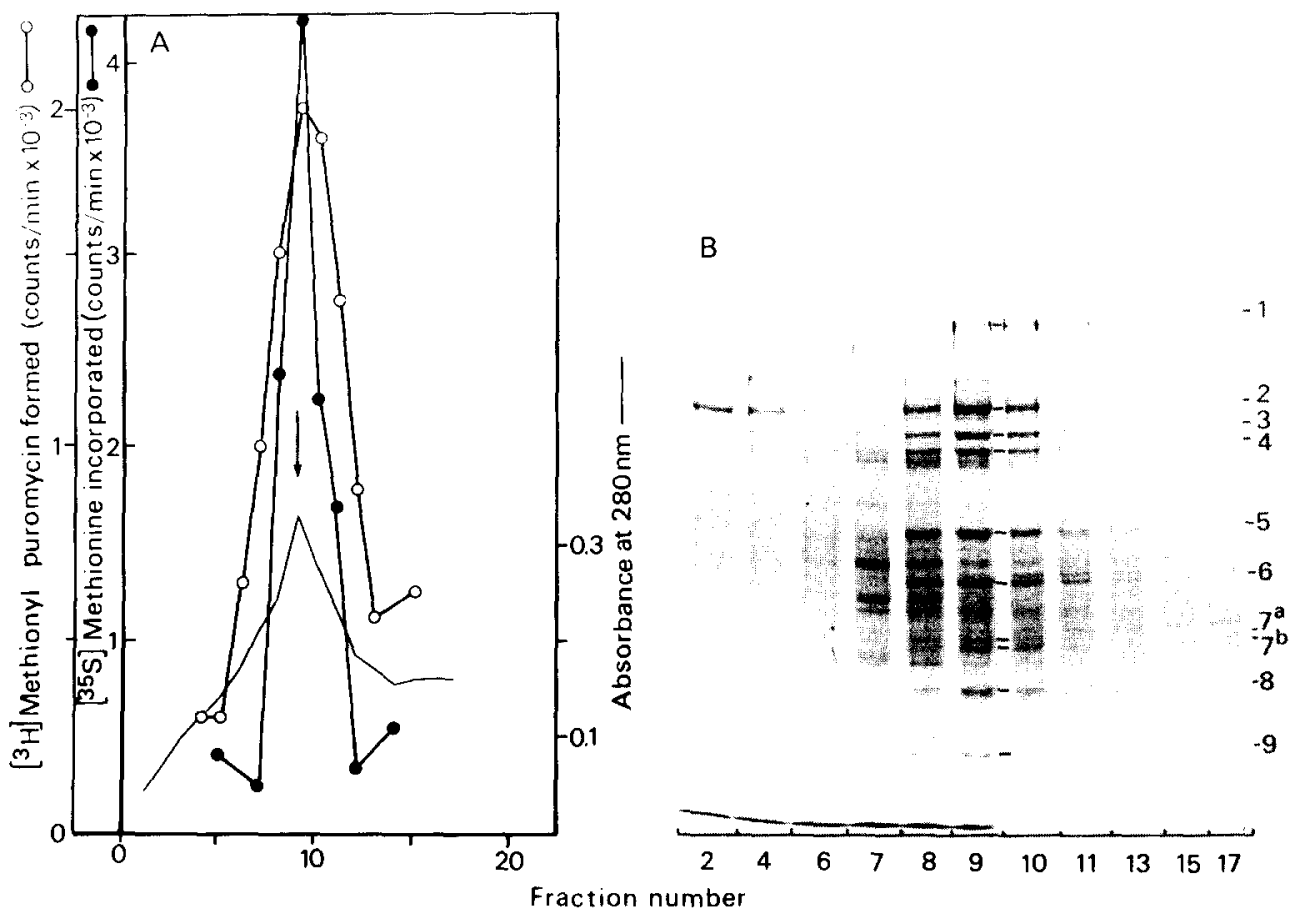

Fig. 2. Analysis of eIF-3 from wheat germ on sucrose gradient. $4.2 \mathrm{mg}$ of eIF-3 following DEAE cellulose was subjected to sucrose gradient centrifugation as described in section Results and Discussion, $0.7 \mathrm{mg}$ of eIF-3 was applied per gradient. A, Activity profile. $10 \mu 1$ of each fraction were assayed for eIF-3 activity in the assay systems for methionyl puromycin formation (I) and for protein synthesis in a pH 4.5 system derived from wheat germ (II) as described under Materials and Methods. A background synthesis obtained in the absence of eIF-3 $(3000 \mathrm{cpm}$ (assay I, $O$ ) or $4000 \mathrm{cpm}$ (assay II, $\bullet))$ has been subtracted. The arrow in the figure corresponds to the position at which $\beta$-galactosidase sedimented in a control gradient. B, Gel analysis. $80 \mu \mathrm{l}$ of each fraction were electrophoresed on a $10 \%$ slab gel according to Laemmli [24]. The lines in the figure indicate the position to which to supposed subunits of eIF-3 migrated.

\section{TABLE II}

\section{SUBUNIT COMPOSITION OF EIF-3}

Molecular weights were calculated from the gels of Figs. 1 and 2 with the following protein standards: phosphorylase $b(90000)$, bovine serum albumin $(67500)$, ovalbumin $(45000)$ and chymotrypsinogen $(25000)$. Stoichiometric determinations were made from densitometric tracings as described [1]. The values obtained were normalized to protein No. 2.

\begin{tabular}{lll}
\hline $\begin{array}{l}\text { Protein } \\
\text { No. }\end{array}$ & $\begin{array}{l}\text { Stoichi- } \\
\text { ometry }\end{array}$ & $\begin{array}{l}\text { Molecular } \\
\text { weight } \\
\left(\times 10^{-3}\right)\end{array}$ \\
\hline 1 & 0.4 & 135 \\
2 & 1.0 & 95 \\
3 & 0.6 & 87 \\
4 & 0.5 & 83 \\
5 & 1.0 & 60 \\
6 & 1.0 & 49 \\
7 a & 0.7 & 39.5 \\
7 b & 0.5 & 38.5 \\
8 & 1.0 & 32 \\
9 & 0.9 & 26
\end{tabular}


The molecular weight of the non-dissociated factor may vary, depending on the precise subunit composition, between 400000 and 500000 , which is in good agreement with a sedimentation coefficient of $15 \mathrm{~S}$.

\section{Biological characterization of eIF-3 from wheat germ}

The activity of eIF-3 from wheat germ was compared to that of the analogous factor from rabbit reticulocytes in a number of assay systems. The results are shown in Fig. 3. The wheat germ factor was virtually inactive in the $\mathrm{pH} 5$ assay system derived from mammalian sources (reticulocytes and liver) which is shown in Fig. 3B. However, the factors from wheat germ and reticulocytes were comparably active in the $\mathrm{pH} 4.5$ system derived from wheat germ (Fig. 3A).

The activity of the wheat germ factor in the assay for methionyl puromycin formation is approximately $15 \%$ of that observed for the reticulocyte factor (Fig. 3C).

Similar observations have been made for eIF-2 from wheat germ [12], which turned out to be considerably less active than the reticulocyte factor when tested in assay systems derived from mammalian sources.

A possible explanation for this difference in activity could lie in the presence of contaminating components in the wheat germ factor preparations which are inhibitory to these (heterologous) assay systems. An alternative explanation is provided if one assumes that species-specific differences exist between the factors from the two sources which cause them to interact poorly with heterologous initiation factors and ribosomes. Their basic mode of action, however, is
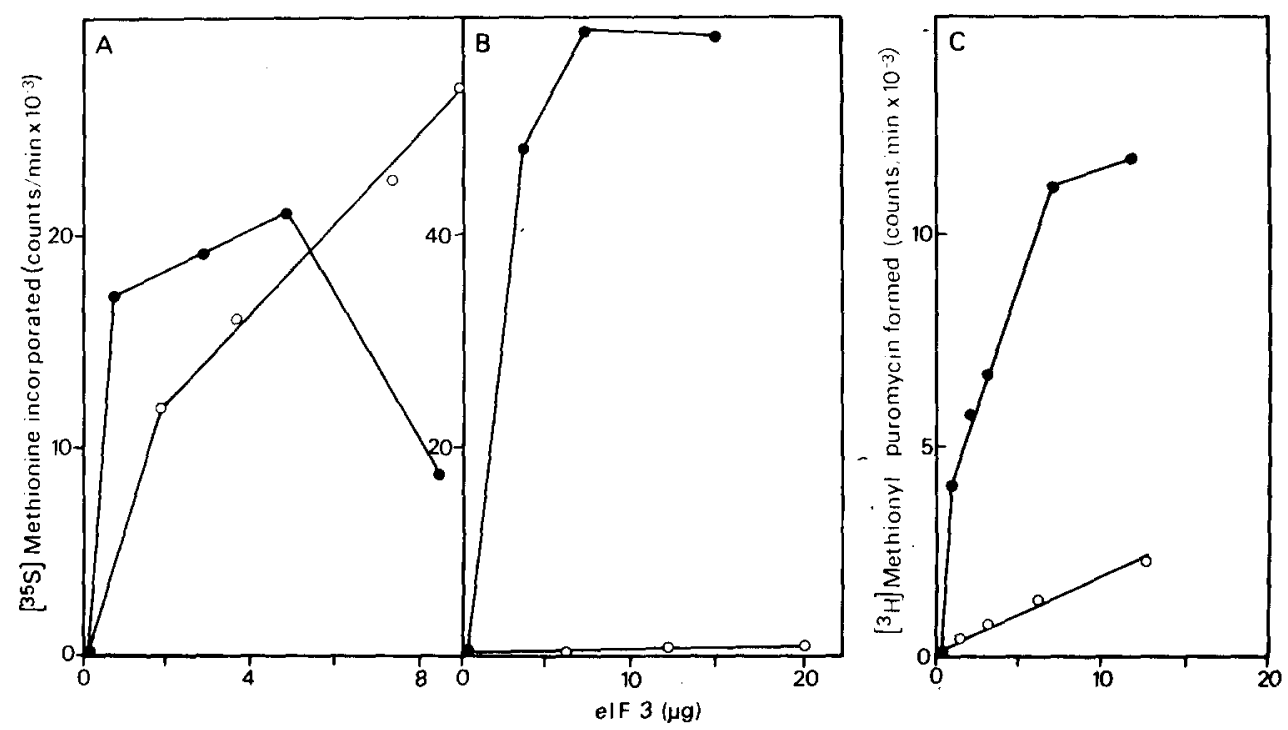

Fig. 3. Activity of eIF-3 from wheat germ and from rabbit reticulocytes. Amounts as indicated of eIF-3 from wheat germ $(O)$ or from rabbit reticulocytes $(\bullet)$ were tested in various assay systems: $\mathrm{A}, \mathrm{pH} 4.5$ assay system derived from wheat germ: B, pH 5 assay system derived from mammalian sources; and C methionyl puromycin synthesis. The experimental details have been described under Materials and Methods and in the legend to Fig. $2 B$. 
similar since eIF-3 from wheat germ shows activity (albeit little) in a model assay system for protein-synthesis initiation (such as the methionyl puromycin formation) derived exclusively from mammalian sources.

eIF-3 from rabbit reticulocytes [8,25] or rat liver [4] is capable of dissociating $80-\mathrm{S}$ ribosomes or preventing the reassociation of the $40-\mathrm{S}$ and $60-\mathrm{S}$ ribosomal subunits.

A recent report [26] indicates that in wheat germ such an activity is displayed by a protein distinct from eIF-3. Therefore, we checked the dissociation and anti-association activity of our eIF-3 preparation from wheat germ, utilizing wheat germ ribosomes.

No activity of wheat germ eIF-3 could be detected in these assays (results not shown), indicating that in wheat germ the dissociation of ribosomes into subunits is not mediated by eIF-3. However, the possibility still exists that eIF-3 stimulates the dissociation activity of other factors.

\section{Acknowledgements}

We thank Drs. H.O. Voorma and A.B. Legocki for their interest and for stimulating discussions.

\section{References}

1 Benne, R. and Hershey, J.W.B. (1976) Proc. Natl. Acad. Sci. U.S.A. 73, 3005-3009

2 Safer, B., Adams, S.C., Kemper, W.M., Berry, K.W., Lloyd, M. and Merrick, W.C. (1976) Proc. Natl. Acad. Sci. U.S.A. 73, 2584-2588

3 Schreier, M.H., Erni, B. and Staehelin, T. (1977) J. Mol, Biol. 116, 727-753

4 Thompson, H.A., Sadnik, I., Scheinsbuks, J. and Moldave, K. (1977) Biochemistry 16, 2221-2230

5 Spremulli, L.L., Walthall, B.J., Lax, S.B. and Ravel, J.M. (1979) J. Biol. Chem. 254, 143-148

6 Benne, R. and Hershey, J.W.B. (1978) J. Biol. Chem. 253, 3078-3087

7 Peterson, D.T., Merrick, W.C. and Safer, B. (1979) J. Biol. Chem. 254, 2509-2516

8 Trachsel, H. and Staehelin, T. (1979) Biochim. Biophys. Acta 565, 305-314

9 Trachsel, H., Schreier, M.H. Erni, B. and Staehelin, T. (1977) J. Mol. Biol. 116, 754-767

10 Safer, B. and Anderson, W.F. (1978) C.R.C. Critical Rev. Biochem. 5, 261 -290

11 Heywood, S.M. (1974) Proc. Natl. Acad. Sci. U.S.A. 71, 2428-2431

12 Benne, R., Kasperaitis, M., Voorma, H.O., Ceglarz, E. and Legocki, A.B. (1980) Eur. J. Biochem. 104, 109-117

13 Van der Mast, C., Thomas, A., Goumans, H., Amesz, H. and Voorma, H.O. (1977) Eur. J. Biochem. $75,455-464$

14 Krystosek, A., Cawthon, M.L. and Kabat, D. (1975) J. Biol. Chem. 250, 6077-6084

15 Benne, R., Wong, C., Luedi, M. and Hershey, J.W.B. (1976) J. Biol. Chem. 251, 7675-7681

16 Benne, R. and Hershey, J.W.B. (1976) Proc. Natl. Acad. Sci. U.S.A. 73, 3005-3009

17 Benne, R., Luedi, M. and Hershey, J.W.B. (1977) J. Biol. Chem. 252, 5798-5803

18 Benne, R., Brown-Luedi, M.L. and Hershey, J.W.B. (1978) J. Biol. Chem. 253, 3070-3077

19 Falvey, A.K. and Staehelin, T. (1970) J. Mol. Biol, 53, 1-19

20 Schreier, M.H. and Staehelin, T. (1973) J. Mol. Biol. 73, 329-349

21 Marcus, A., Seal, S.N. and Wechs, D.P. (1974) Methods Enzymol. 30, 94-101

22 Thomas, A., Goumans, H., Amesz, H., Benne, R. and Voorma, H.O. (1979) Eux. J. Biochem. 98 , $329-337$

23 Layne, E. (1957) Methods Enzymol. 3, 451-454

24 Laemmli, U.K. (1970) Nature (Lond.) 227, 680-685

25 Thomas, A., Goumans, H., Voorma, H.O. and Benne, R. (1980) Eur. J. Biochem. 107, $39-45$

26 Russel, D.W. and Spremulli, L.L. (1979) J. Biol. Chem. 254, 8796-8800 